Nalar: Jurnal Peradaban dan Pemikiran Islam

Vol. 2, No. 1, Juli 2018

\title{
Ijtihad Epistemologis Muslim Progresif Omid Safi dan Respon Atas Tantangan Global
}

\author{
Muhammad Syafi'i \\ Universitas Islam Negeri Sunan Kalijaga Yogyakarta, Indonesia \\ syafii313@gmail.com
}

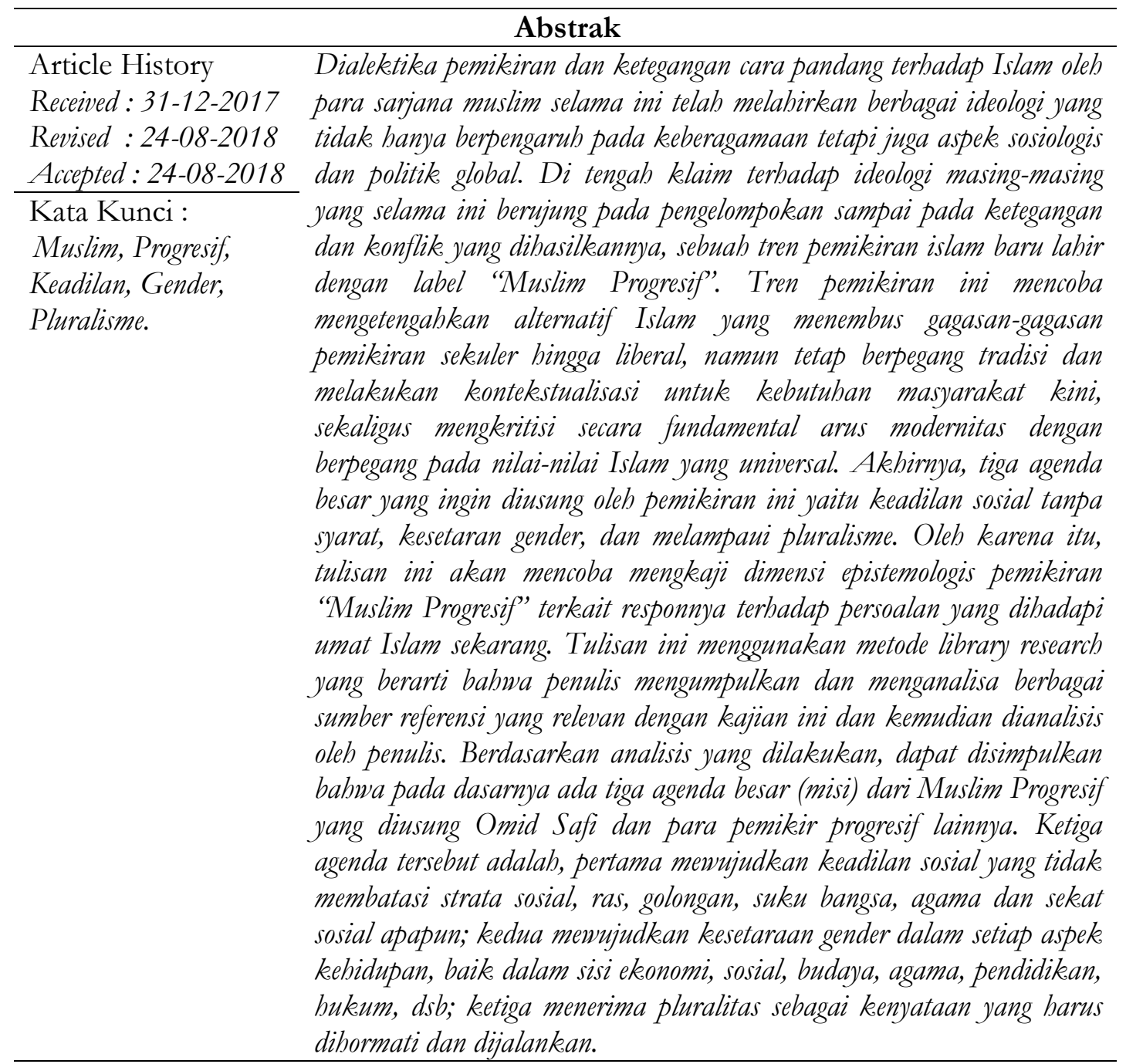

\section{Pendahuluan}

Pasca runtuhnya menara kembar WTC Amerika Serikat atau yang dikenal dengan peristiwa 9/11, publik seluruh dunia mengalami goncangan dan ketakutan. Amerika yang berposisi sebagai negara adidaya segera mengambil langkah identifikasi dan menjadikan peristiwa tersebut sebagai "extraordinary crime", melakukan proteksi tingkat tinggi guna menghindari terulangnya peristiwa tersebut. "Islam" kemudian disebut-sebut sebagai dalang dalam peristiwa tersebut (Ehrke, 2001). Terlepas dari apakah Islam atau siapakah Islam yang dimaksud, yang jelas, hubungan aksi teror dengan Islam telah memberikan gambaran yang common sense di dunia Barat bahwa Islam dekat dengan terorisme dan kekerasan. Kondisi ini bahkan masih terasa sampai sekarang. 
Nalar: Jurnal Peradaban dan Pemikiran Islam

Vol. 2, No. 1, Juli 2018

Realitas ini memunculkan respon di kalangan pemikir dan akademisi baik yang muslim maupun non muslim. Respon tersebut kemudian menghasilkan berbagai gagasan yang pada intinya memberikan klarifikasi terhadap hubungan Islam dan terorisme tersebut. Di sisi lain, serbuan modernitas yang semakin gencar membuat para pemikir Muslim semakin gelisah diiringi dengan klaim terhadap kebenaran masing-masing. Persoalannya sebagian pemikir muslim ada yang bersikap acuh tak acuh pada Islam yang hadir di masa kini. Muncul kemudian sikap memberi jarak pada kenyataan dan lebih memilih mewujudkan "Islam Imajinatif", yang menjadi mitologi zaman kemarin maupun utopia masa depan. Lebih parah lagi, melakukan aksi kekerasan mengerikan sehingga menyentak kesadaran semua orang, termasuk nonmuslim (Zaqzuq, 2004: 44).

Sebagai agama yang mengandung nilai-nilai universal, Islam dalam perjalanannya mampu menembus ruang dan waktu, yang pada gilirannya akan mempengaruhi paradigma para pemikir Islam melalui berbagai macam perubahan dan penyesuaian baik secara evolusi maupun revolusi, yang sudah barang tentu kesemuanya ditujukan dan bertujuan dalam rangka mengagungkan Din al-Islam (Qomar, 2012). Sehingga suatu hal yang sulit dihindari dalam dinamika pemikiran keagamaan adalah ketegangan-ketegangan dan bahkan konflik yang muncul mengiringi perkembangan pemikiran tersebut (Zubaedi, 2013: 7).

Di satu pihak ketegangan itu muncul oleh suatu keharusan mempertahankan sendi doktrinal norma agama dan situasi dunia yang selalu berubah. Sedangkan di pihak lain ketegangan tersebut lahir dari oleh proses sosiologis. Meski demikian pergulatan-pergulatan pemikiran dan gagasan keagamaan pada akhirnya memberi dasar bagi proses sosial, setelah terlebih dahulu gagasan itu teruji dan tahan atas falsifikasi.

Berbagai pergulatan dan ketegangan yang mewarnai berbagai pemikir Muslim ini akhirnya berujung pada pengelompokkan Islam sebagai gerakan dengan berbagai macam label seperti tradisionalis, modernis, liberalis, sekular, ekstrimis, kritis, dan sebagainya (Qomar, 2012). Di tengah-tengah identifikasi dan pengelompokkan muslim ini, sebuah tren baru pemikiran Islam hadir dengan melabelkan diri sebagai "Muslim Progresif", dengan inisiatornya yaitu Omid Safi.

Omid Safi yang tinggal di Amerika memiliki peranan penting dalam upaya menampilkan wajah Islam yang mampu mematahkan klaim yang selama ini mengakar di Barat. Safi mengemukakan bahwa pencetusan "Muslim Progresif' merupakan upaya untuk melawan tuduhan yang selama ini berkembang di Barat bahwa Islam itu agama yang keras, kaku, tidak menghargai hak-hak perempuan, tidak mengedepankan HAM, dan fanatis. Melihat konteks Islam yang hidup pada masa Omid Safi di mana gagasannya membumi dan menyedot perhatian dunia muslim, maka tulisan ini akan berusaha untuk mengungkapkan tema pokok tentang "Muslim Progresif" yang digagas oleh Omid Safi, dan pemikir muslim progresif lainnya.

Fokus studi ini adalah untuk menganalisis pemikiran Omid Safi tentang wacana Muslim Progresif. Pada dasarnya studi yang dilakukan ini merupakan studi pustaka (library research). Studi pustaka adalah sebuah penelitian yang dilakukan dengan menganalisis berbagai literatur yang berhubungan dengan fokus yang diteliti. Oleh karena itu, sumber data dalam studi ini adalah berbagai literatur yang relevan dengan fokus kajian. Hasil analisis tersebut kemudian dikerucutkan kepada sebuah kesimpulan yang relevan dengan fokus kajian yang diteliti.

\section{Muslim Progresif: Kelahiran dan Makna}

Istilah Muslim Progresif sesungguhnya telah lahir dengan berdirinya sebuah organisasi bernama Progressive Muslims Network pada tahun 1999 di Toronto, Kanada 
Nalar: Jurnal Peradaban dan Pemikiran Islam

Vol. 2, No. 1, Juli 2018

(Mu'ammar, 2013: 367). Namun, sebagai sebuah pemikiran yang segar istilah ini muncul melalui seorang Omid Safi dan beberapa rekannya dalam sebuah gagasan yang tertuang dalam buku Progressive Muslim: On Justice, Gender, and Pluralisme. Omid Safi sendiri adalah seorang warga Amerika Serikat berdarah Iran. Ia menjadi asisten profesor Filsafat dan Agama di Universitas Colgate. Ia juga adalah anggota Steering Commite untuk Studi Islam di American Academy of Religion (Safi, 2003: x). Melihat posisi Omid Safi dalam konteks ini maka wajar jika gagasan Muslim Progresif mampu menembus dan menggugah para pemikir di dunia internasional.

Muslim progresif adalah konsep dasar yang menjadi rumah bagi orang-orang yang menginginkan ruang terbuka dan aman untuk menjalankan suatu keterlibatan yang ketat dan jujur dengan tradisi, dan penuh harap akan menghantarkan lebih lanjut kepada aksi (Safi, 2003: 17-18). Merujuk pada salah satu artikel yang terbit di halaman Wahid Institute di tahun 2005, Ahmad Suaedy mengungkapkan bahwa apa yang dimaksud dengan Muslim Progresif adalah merujuk kepada dua tokoh yang salah satunya sudah disebutkan yaitu Omid Safi dan Farish A. Noor dari Malaysia. Farish menulis cukup panjang tentang topik ini yang banyak beredar di mailing list maupun berbicara di beberapa seminar dan diskusi. Sedangkan Safi menulis buku yang merupakan kompilasi dari berbagai tulisan para intelektual dan aktivis dari negara-negara Islam (wahidinstitute.org, 2017)

Farish maupun Safi dalam hal ini memiliki pandangan yang berbeda tetapi masih dalam visi yang sama. Farish fokus pada pentingnya para aktivis Muslim Progresif ini untuk melihat fenomena globalisasi dan melakukan kritik karena secara nyata telah melahirkan ketidakadilan dan ketimpangan yang merambah sampai ke ranah lokal. Muslim Progresif baginya mesti meleburkan diri ke dalam kelompok anti-globalisasi. Farish menambahkan, perlunya legitimasi keagamaan, termasuk dalam istilah-istilah teknis keagamaan terhadap tujuan perubahan itu sendiri seperti demokrasi dan anti-globaliasi. Tentu saja, ini dalam upaya mengimbangi kelompok reaksioner dan konservatif yang melakukan legitimasi dan menggunakan istilah-istilah keagamaan untuk gerakannya (Noor, 2006: 23).

Sedikit berbeda dengan Farish, pandangan muslim progresif Omid Safi terfokus lebih pada usaha menyebarkan nilai-nilai muslim progresif secara intelektual maupun gerakan atas fenomena ketimpangan sosial secara rasional. Selain itu muslim progresif juga berperan dalam mendorong umat Islam untuk lebih membuka pandangan terkait pluralitas masyarakat, tuntutan kesetaraan gender, dan fenomena ketidakadilan. Dengan begitu, kesemua elemen masyarakat maupun intelektual ikut ambil bagian dalam proses analisis sosial dan gerakan perubahan itu sendiri. Keadilan, kesetaraan gender, dan pluralisme merupakan tiga agenda besar dalam muslim progresif (Safi, 2003: 2).

Tiga gagasan tersebut merupakan hasil dari satu tema utama yang dalam beberapa kurun terakhir merupakan isu paling krusial melanda umat manusia, yaitu tentang krisis kemanusiaan. Saat ini umat Islam harus berpikir tentang kemanusiaan sebagai suatu anugerah Ilahi yang berharga. Untuk itu perlu sebuah upaya berdasarkan kepada semangat optimisme dan kritik yang simultan (Coulson, 1964: 75). Safi bersama para pemikir lain menyadari bahwa permasalahan yang muncul pada dasarnya merupakan masalah yang rumit, dan karenanya pula membutuhkan analisis dan jawaban yang rigid. Muslim progresif berusaha untuk memulai suatu proses agar sampai pada tujuan yang dicita-citakan. Meminjam kata-kata Dylan yang dimaknai oleh Safi, muslim progresif harus mulai berenang mengarungi, melewati gelombang Islam dan modernitas, berusaha dengan sekuat tenaga untuk mewujudkan keadilan di tengah-tengah masyarakat global. Inilah makna kemajuan dari kata progresif yang ingin ditekankan oleh Safi (Safi, 2003). 
Nalar: Jurnal Peradaban dan Pemikiran Islam

Vol. 2, No. 1, Juli 2018

Ebrahim Moosa mengungkapkan siapapun yang berfikir bahwa Muslim Progresif adalah sebuah ideologi, kredo, gerakan, atau sekumpulan doktrin yang siap-pakai pasti akan sangat kecewa (Moosa, 2007: 115). Muslim Progresif beranggapan bahwa zaman telah berubah dan dengan otomatis realitas juga berubah. Fenomena perubahan tersebut tidak terjadi begitu saja, melainkan ada faktor-faktor yang mendorong terjadinya perubahan, baik itu adanya faktor ekonomi, sosial, politik dan stuktural. Kemampuan dan kesanggupan untuk merombak dan memperbarui aspek normatif Islam yang dianggap kuno, menjadikan muslim yang satu ini lebih progres dibandingkan dengan muslim lainnya. Tetapi tidak jarang progresif dimaknai dengan kemajuan yang berujung pada lahirnya kebebasan yang justru menciptakan liberalisme yang tidak terkendali (Abdullah, 2009: x).

Kesan elitis dan arogan yang tampak dalam istilah progresif bagi Safi merupakan tantangan berat Muslim Progresif itu sendiri. Ia menawarkan gagasan itu sebagai sebuah "alternatif", bukan sesuatu yang sepenuhnya "antagonistik" bagi arus-utama umat Islam. Lebih jauh, untuk menghindarkan istilah itu dari kesan elitis, Safi menyarankan agar ia harus terlibat dalam tindakan dan transformasi sosial yang konkret (Safi, 2003: 8). Ini yang kemudian membuatnya menolak menjadi Muslim Kritis, karena cenderung hanya terusmenerus mengeluh tanpa berbuat aksi nyata ke masyarakat (Safi, 2003: 8).

Istilah progresif dipilih sesungguhnya bukan karena kata tersebut paling representatif, namun lebih karena tidak ada kata lain yang lebih tidak bermasalah. Terkait dengan hal tersebut Ebrahim Moosa mengatakan bahwa dirinya menggunakan istilah tersebut sambil memprotesnya juga(Moosa: 125). Sementara kata muslim dipilih bersanding dengan progresif dikarenakan yang memiliki sifat progresif dan tidak progresif adalah pemeluk agama Islam, bukan agama Islam itu sendiri. Dengan begini tanggung jawab muslim itu sendirilah untuk menjadikan dirinya progresif atau tidak (Safi, 2003: 10).

\section{Pijakan Metodologis Muslim Progresif}

Sebagai tokoh yang mewakili Muslim Progresif, Omid Safi menawarkan pendekatan Multiple Critique atau kritik ganda dalam melihat berbagai persolan. Kritik ganda adalah sebuah pendekatan beragam arah (a multibeaded approach) yang didasarkan atas kritik simultan terhadap beragam komunitas dan wacana yang melibatkan banyak orang di dalamnya" (Safi, 2003: 2). Kritik-ganda ini selanjutnya merupakan kritik pisau bermata dua, di satu sisi untuk mengkritik umat Islam sendiri dan sisi lain mengkritik Barat. Pijakan kritik ini bersumber pada nilai mendasar bahwa setiap manusia muslim maupun nonmuslim, laki-laki maupun perempuan, kaya dan miskin, dan seterusnya memiliki nilai yang sama. Dalam pandangan Safi, ketidakadilan mungkin telah terjadi atas nama Islam, di sisi lain hegemoni Barat juga ikut melanggengkan ketidakadilan, keduanya adalah bagian yang harus dibongkar dan diperbaiki. Bahkan untuk Muslim Progresif sendiripun harus terus-menerus dikritik jika ia cenderung menjadi kaku, otoriter, dan dogmatis (Safi, 2003: 4).

Muslim progresif selanjutnya juga mengkritik pemaknaan teks hukum Islam yang diskriminatif terhadap perempuan sekaligus menolak eksploitasi wanita di Barat. Di satu sisi, muslim progresif mengkritik persekusi kelompok minoritas di negara-negara Muslim. Sedangkan, di sisi lain, muslim progresif juga menyoal kebijakan luar negeri Amerika Serikat yang selalu agresif mengadu domba negara-negara Muslim. Muslim progresif memilih visi tentang Islam yang berbeda dari kelompok Wahabi atau Neo-Wahabi, akan tetapi di sisi lain juga menolak untuk menjadi sekular. Pemikiran muslim progresif juga sangat mengkritisi dan mendebat orang-orang Islam yang tiada henti-hentinya membenci dan memusuhi Barat (Muslim Westhernmophobes), seperti Usmah bin Laden, Ayman al-Zawahiri, dan Sulaiman Abu Ghayt. Namun di sisi lain, muslim progresif mengecam orang-orang Barat yang tiada henti- 
Nalar: Jurnal Peradaban dan Pemikiran Islam

Vol. 2, No. 1, Juli 2018

hentinya membenci dan menyerang Islam (Western Islamophobes), seperti Bernard Lewis, Samuel P. Huntington, Daniel Pipe, dan Robert Spencer (Safi, 2007: 199-210).

Secara lebih mendalam, Safi (2003: 4-5) memberikan beberapa tawaran pengembangan dari Multiple Critique yang digagasnya. Pertama, keterlibatan penuh dalam tradisi Islam. Pemikiran muslim progresif dalam pandangan Safi menolak konservativisme yang menganggap tradisi Islam harus dipelihara dalam bentuknya yang sama seperti warisan masa Rasulullah. Selain itu Safi juga mengkritik sekularisme dan rejeksionisme yang menganggap bahwa tradisi Islam itu harus ditolak sepenuhnya. Bagi Safi, tradisi Islam itu harus dipandang sebagai a tradition in becoming, tradisi yang terus berkembang dan mencari bentuk yang sesuai dengan tantangan baru yang dihadapinya. Strateginya adalah dengan mengangkat ke permukaan isu-isu yang umat Islam enggan membicarakannya secara terbuka. Kedua, menolak sikap apologis dan simplistik. Persoalan umat manusia dan umat Islam masa kini sudah terlampau kompleks. Pada tataran ini, Safi menolak kecendrungan Islam Pamflet yang merujuk kepada ajaran Islam yang sederhana dan monolitik. Kedua, penekanan terhadap upaya transformasi dan tindakan yang konkrit. Muslim progresif menganggap penting visi sekaligus aktivisme. Tindakan sosial yang konkrit misalnya harus ditujukan untuk seluruh umat manusia, bukan hanya muslim saja. Ketiga, perhatian kepada humanisme Islam dan adab. Humanisme merupakan landasan filosofisnya sementara adab merupakan kode hubungan lahiriah antar manusia. Pada titik ini, Safi menekankan pentingnya menyelami tradisi tasawuf karena at-tashawnuf kullubu al-adab. Keempat, keterbukaan terhadap sumber pengetahuan dan kebijaksanaan. Omid Safi memandang bahwa hidup di abad ke-21 tidak cukup hanya dengan bermodal Al-Qur'an dan Hadits. Muslim progresif juga perlu mengenal sumber-sumber kebijaksanaan lain yang sekunder seperti Rumi, Ibnu 'Arabi, Plato Ibnu Sina, Chomsky, Ghandi, Robert Fisk, Edward Said, Bob Dylan, Bob Marley, dan sebagainya. Tawaran Omid Safi pada dasarnya ingin menegaskan bahwa epistemologi Muslim Progresif adalah epistemologi yang pluralistik atau meminjam istilah Amin Abdullah yaitu Cross-Reference yang bersifat integarif-interkonektif (Abdullah, 2012: vii-viii).

\section{Agenda Muslim Progresif: Respon terhadap Berbagai Tantangan di Era Global}

Kelahiran pemikiran muslim progresif bersumber dari ayat-ayat Al-Quran yang secara nyata dan tegas menjunjung nilai kemanusiaan. Tiga agenda besar muslim progresif yaitu keadilan sosial, kesetaraan gender, dan pluralisme merupakan hasil ijtihad panjang melalui berbagai diskusi dan perdebatan lintas benua dan bahasa. Hasil ijtihad ini setidaknya merupakan pertimbangan serius yang mencakup pandangan bahwa setiap manusia, laki-laki maupun perempuan, muslim dan non-muslim, kaya dan miskin, timur dan barat, selatan dan utara, adalah sama-sama manusia yang memiliki nilai kemanusiaan yang diberikan oleh Tuhan dalam dirinya. Nilai ini menurut al-Qur'an, adalah ruh ketuhanan yang dihembuskan kedalam diri manusia dalam proses penciptaan. QS al-Hijr: 29 dan as-Shad: 71 merupakan dalil kuat mengenai hal ini (Setiawan, 2008: 21).

Dengan demikian, karena misi Al-Qur'an secara universal adalah misi kemanusiaan maka kehadiran manusia di dunia adalah menjadi pejuang dan penegak keadilan (al'adl/justice) berbasis nilai-nilai kemanusiaan. Manusia tanpa memandang atributnya apa, wajib berbuat kebajikan dan berperilaku santun kepada sesama makhluk Tuhan. Untuk ini, QS al-Nahl: 90 mampu mewakilinya. Melalui pemikiran yang lahir dari dimensi keruhanian manusia ini, tren pemikiran muslim progresif menghidupkan dirinya dalam pegangan kuat sekaligus kritis terhadap tradisi Islam (critical engagement) dan modernitas (multiple critique) (Setiawan, 2008: 21). 
Nalar: Jurnal Peradaban dan Pemikiran Islam

Vol. 2, No. 1, Juli 2018

Pemikiran Muslim Progresif sebagaimana termuat dalam buku Progressive Muslims on Justice, Gender and Pluralism meliputi tiga wilayah diskursus dan aksi, yaitu keadilan sosial, kesetaraan gender, dan pluralisme. Pertama, keadilan Sosial Tanpa Syarat. Salah satu tolak ukur seseorang bisa dikatakan muslim progresif adalah ketika sanggup memberikan keadilan sosial bagi sesama manusia. Keadilan merupakan salah satu persoalan pokok yang disadari umat manusia semenjak mengenal kehidupan bernegara. Misalnya pada masa Plato dengan pikiran-pikirannya mengenai negara republik masalah keadilan dalam pemerintahan banyak menyibukan para pemikir, khususnya para pemimpin agama yang saat itu merupakan satu-satunya kasta yang "melek huruf" dalam masyarakat. Sedang para ahli sejarah berpendapat bahwa cita-cita keadilan umat manusia itu pertama kalinya secara hukum mewujud nyata dalam Hukum atau Kode Hammurobi (Code of Hummuroby) yang berlandaskan keadilan (Majid, 2008: 503).

Muslim progresif dalam hal ini memandang keadilan adalah dasar terciptanya kedamaian. Artinya kedamaian tidak mungkin tercipta sebelum keadilan itu terbangun dan hendaknya tidak hanya diartikan sekedar "aman" atau "tidak adanya perang dan perkelahian", karena hal itu dapat menjadi kedok untuk memapankan tirani dan struktur sosial yang tidak adil. Jadi memperjuangkan tegaknya keadilan lebih diutamakan ketimbang hanya mempertahankan situasi "aman" atau "tidak adanya perkelahian" (Safi, 2006: 10).

Pemimpin dalam hal ini mesti adil dan memberikan kenyamanan di tengah-tengah masyarakat tanpa membeda-bedakan ras, suku, dan budaya. Adil dalam pemenuhan hak dan keputusan, karena setiap orang mempunyai hak untuk hidup dan memperoleh penghidupan. Mengutip kata Imam Al-Ghazali: "Imārat ad-dunyā wa kharäbuhā min al-mulūk", bahwa kelestarian dan kehancuran dunia sangat ditentukan oleh para penguasa.

Memperjuangkan keadilan bisa bermakna sebagai melihat setara umat manusia, manusia makhluk yang equal, bertanggung jawab untuk kebaikan dan kemuliaan manusia, melawan orang-orang yang menebar kebencian atas nama Islam, yang tuhannya ibarat monster pendendam yang menyuruh membunuh siapa saja, yang Tuhannya terlalu kecil, lemah, sukuistik, dan lelaki. Ini tentu saja dapat ditempuh melalui Ide-ide sosial dalam alQur'an yang dibumikan dengan cara yang dapat dirujuk dan dipahami para aktivis keadilan sosial dengan bersandar pada QS. Al Maidah: 32 yang memberi makna perlindungan pada jiwa-jiwa manusia (Auda, 2008).

Dalam konteks global masa kini, umat Islam dalam konteks masa kini melihat seluruh manusia tanpa kecuali sebagai tetangga-tetangganya yang harus dibela dari segala bentuk ketidakadilan. Menegakkan keadilan tidak sekadar berwacana, tetapi melawan siapapun yang terus-menerus menyebarkan kebencian atas nama Islam, sekaligus juga mengkritik berbagai bentuk korporasi yang mencoba mencari keuntungan dengan mengorbankan masyarakat lokal. Menolak siapapun yang mengira masyarakat muslim sama sekali steril dari rasisime dan penindasan, sambil pada saat yang sama mengecam keras pihak-pihak tertentu di Barat yang memegang hak paten obat-obatan anti-HIV dan membiarkan jutaan orang meninggal karena AIDS.

Kedua, kesetaraan Gender: Rekonstruksi Nilai-Nilai Maskulin dan Feminin. Kesetaraan gender merupakan proyek yang tak bisa dilepaskan dari progressive muslim. Kesetaraan gender juga menjadi bagian dari keadilan sosial. Jika merujuk pada sejarah, kesetaraan gender pada dasarnya sudah diajarkan oleh Nabi lima belas abad silam. Konsep kesetaraan tersebut terutama mengenai hak-hak dan kewajiban seorang perempuan. Rasulullah SAW sering sekali mendelegasikan A'isyah untuk mengajarkan materi-materi tertentu dalam ajaran Islam, atau sebaliknya sahabat perempuan mempunyai akses yang sama dengan sahabat laki-laki untuk bertanya, berdiskusi, dan menerima langsung ajaran 
Nalar: Jurnal Peradaban dan Pemikiran Islam

Vol. 2, No. 1, Juli 2018

dari Nabi. Bila pada perjalanannya banyak terjadi diskriminasi gender, maka hal itu dikarenakan adanya penafsiran yang tidak sempurna dari Al-Qur'an dan Hadits bedasarkan kaum tertentu, sehingga posisi perempuan selalu di marjinalkan (Shihab, 1998: 179).

Ruang publik akhirnya memberi tempat bagi gerak perempuan yang terbatas, seolah berada di rumah kaca. Pada tataran ini wanita hanya mampu memandang dunia dari bilik jendela, tidak ada kuasa untuk keluar menjejali aktivitas di luar ruangan. Selain itu, dalam kondisi ini seakan dapur adalah ruang gerak satu-satunya bagi perempuan untuk berkarya, sekalipun semua itu bukanlah keinginannya. Padahal di luar apabila diamati begitu banyak warna-warni dunia yang bisa dirasakan oleh perempuan sama halnya dengan laki-laki. Tetapi justru selalu dipaksa oleh aturan yang tidak terikat untuk terus berada di tempat yang tidak diinginkannya (Safi, 2003: 237).

Semua pekerjaan domestik yang seolah tiada habisnya seringkali menyebabkan tidak ada ruang bagi perempuan untuk berpikir. Sebagai manusia semestinya perempuan berhak mendapatkan hak yang sama dengan seorang laki-laki, mengingat semua manusia adalah sama yang membedakan adalah pada esensi taqwa. Oleh karena itu ada yang perlu di catat dari pemikiran Omid Safi adalah kesetaraan dan keadilan gender harus diberikan kepada kaum perempuan bukan sebagai hadiah atau belas kasihan, melainkan karena perempuan adalah bagian dari umat manusia yang memang memiliki hak yang melekat atas semua yang semestinya didapatkan.

H.T Wilson dalam Sex and Gender mengartikan gender sebagai suatu dasar untuk menentukan faktor budaya dan kehidupan kolektif dalam membedakan laki laki dan perempuan (Wilson, 1989: 67). Selama ini banyak dari kalangan masyarakat yang memahami kesetaraan gender hanya sebagai perangkat feminisme saja. Padahal dalam kasus ini kesetaraan gender bukan hanya terletak pada atribut feminisme seperti lipstik, bedak, belaka, tetepi kesetaraan gender seharusnya lebih di fokuskan kepada eksistensi perempuan di ruang publik. Sebagai upaya menepis semua praduga yang dilontarkan kaum laki-laki maka timbulah gerakan-gerakan yang di pelopori oleh kaum prempuan. Gerakan-gerakan feminis di dunia Islam mengambil inspirasinya kebanyakan berasal dari sumber-sumber sekuler. Muslim progresif mengupayakan hal-hal lain yang belum tersentuh dan mengusahakan apa yang secara sah diakui sebagai feminisme Islami, Sa'diyya Shaikh menyebutnya sebagai feminism Islami transformatif (transformative Islamic feminism). Feminisme meyakini partikularitas konteks dan keragaman identitas perempuan, memadukan diskursus feminis dengan artikulasi perempuan muslim tentang keterlibatan dalam isu-isu gender, menciptakan ruang dialog yang bermakan dan persaudaraan horizontal (horizontalcomra-dership) antara perempuan muslim dengan perempuan dari kontek religio-kultural yang lain (Gwendolyn: 240).

Kehadiran feminisme merupakan upaya positif dalam rangka menuju keadilan. Proses peralihan masyarakat dari matriarchal clan ke patrialchal family mengemukakan bahwa perkembangan masyarakat beralih dari collective production ke private property dan sistem exchange yang semakin berkembang. Proses peralihan ini menyebabkan perempuan tergeser, karena fungsi reproduksi perempuan dikaitkan dengan produksi. Perbedaan fisik laki-laki dan perempuan sebenarnya sangatlah tidak patut apabila digunakan sebagai alasan untuk memperkuat dan memperkokoh pengakuan di masyarakat, melainkan perbedaan tersebut seharusnya dijadikan sebagai rahmat yang harus di jaga. Pada dasarnya, muslim progresif berangkat dari sebuah prinsip mendasar bahwa keadilan gender bukanlah sesuatu yang dihadiahkan atau dikembalikan kepada kaum wanita, sebab hak-hak tersebut murni milik perempuan sebagai seorang manusia (Dzuhayatin: 82). 
Nalar: Jurnal Peradaban dan Pemikiran Islam

Vol. 2, No. 1, Juli 2018

Ketiga, pluralisme: Melampaui Toleransi (Beyond Pluralism). Pluralisme memberikan kebebasan dan kesempatan bagi setiap orang yang menjalani kehidupan menurut keyakinan masing-masing. Manusia ada bukan untuk bermusuhan tapi hidup untuk bersinergi bersama membangun keharmonisan. Globalisasi telah merambah keseluruh dunia menandai kehidupan yang tanpa batas geografis. Dengan lenyapnya batas ini, umat beragama di dunia harus mempunyai visi yang tepat tentang agama dengan kesadaran yang positif akan adanya perbedaan (Wahid, 2012: 65).

Kesadaran diri masing-masing kelompok dan segala perbedaannya mesti benarbenar dipahami dan dipertimbangkan secara serius. Dalam hal ini, pluralisme menjadi ikatan murni dari berbagai peradaban yang ada (Majid: 112). Karenanya Muslim progresif menempatkan pluralisme sebagai tantangan besar bukan saja menjadi muslim tetapi juga bagi umat manusia. Konsepsi pluralisme pada dasarnya memandang manusia bukan berdasarkan kelompoknya, tetapi memandang sebagai bagian dari bani Adam.

Mengenai bani Ädam ini, Al-Qur'an setidaknya tujuh kali menyebutkannya di mana secara harfah yang berarti anak-anak Adam, yang merujuk kepada pengertian keseluruhan umat manusia, yaitu: QS.al A'raf: 26,27,31,172, al-Isra': 70, dan Yâsin: 60. Dalam ayat-ayat itu al-Qur'an menantang, menggerogoti, dan menghapus kebiasaan kesukuan yang sempit pada masa pra-Islam, dan menggambarkan segenap manusia sebagai fanggota satu maha suku, suku manusia. Oleh karena itu, bagi setiap muslim tiada ada pilihan lain selain memenuhi pesan al-Qur'an. Nabi Muhammad pun menyatakan hubungan manusia satu dengan manusia lainnya ibarat anggota dalam satu tubuh; ketika satu anggota tubuh menderita sakit maka anggota lainnya ikut merasakan perih dan ketidaknyamanan (Safi, 2006: 11-12). Jadi, persoalannya bukanlah terletak pada perbedaan antar keyakinan, pendapat, ideologi, tetapi bagaimana cara mendialogkan, mencari titik temu antar perbedaan agar tidak ada kesenjangan sosial.

Omid Safi memandang bahwa pluralisme dapat terwujud apabila setiap individu sanggup untuk menghormati dan melibatkan orang atau kelompok lain (the others) pada titik terdalam dari sesuatu yang menjadikan semua manusia dalam kedudukan yang sama. Pluralisme adalah ketika manusia dapat mengatakan "kita" dan yang dimaksud adalah manusia secara menyeluruh (Bani Adam), terlepas dari semua perbedaan dan persamaan yang ada. Pluralisme bisa disebut sebagai lawan dari klasifkasi eksklusif berdasarkan apapun (Safi, 2003: 14). Oleh sebab itu, Safi menolak konsep toleransi karena dalam istilah terebut mengandung asumsi bahwa "yang lain" tersebut adalah sejenis racun yang dapat ditoleransi hingga batas ketahanan tertentu. Safi juga mengkritik slogan Islam merupakan agama perdamaian, sebab slogan tersebut memiliki kecenderungan pemahaman bahwa dalam Islam sekalipun ada manusia manusia yang tidak cinta damai, serta karena perdamaian bisa saja dimaknai sikap diam dan pasrah serta tenang menghadapi penindasan (Safi, 2003: 15).

\section{Kesimpulan}

Ijtihad muslim progresif yang mencoba menawarkan alternatif baru dalam metodologi pemikiran Islam tampaknya memiliki signifikansi yang kuat dalam mempengaruhi cara berfikir muslim kontemporer kini. Siapapun mampu tergolong ke dalam corak pemikir ini ketika karakteristik yang telah dijalaskan di atas masuk dalam kategorinya. Namun untuk mendekatkan pada tren pemikiran yang berkembang dalam dunia muslim kontemporer. Muslim rogresif lebih dekat dengan corak berfikir Islam Progresif yang dikembangkan oleh Abdullah Saeed meskipun Omid Safi mengklaim tidak demikian. 
Nalar: Jurnal Peradaban dan Pemikiran Islam

Vol. 2, No. 1, Juli 2018

Pada dasarnya ada tiga agenda besar (misi) dari Muslim Progresif yang diusung Omid Safi. Ketiga agenda tersebut adalah, pertama mewujudkan keadilan sosial yang tidak membatasi strata sosial, ras, golongan, suku bangsa, agama dan sekat sosial apapun. Kedua mewujudkan kesetaraan gender dalam setiap aspek kehidupan, baik dalam sisi ekonomi, sosial, budaya, agama, pendidikan, hukum. Ketiga menerima pluralitas sebagai kenyataan yang harus dihormati dan dijalankan. Metode yang diadopsi oleh Omid Safi dalam mengkonstruksi konsep tentang Muslim Progresif adalah metode multiple critique. Dalam makna yang sangat sederhana, istilah ini dapat diterjemahkan sebagai kritik-ganda, dimana umat Muslim harus mampu mengkritisi diri sendiri disatu sisi dan juga haraus mampu mengkritisi Barat dalam sisi yang lain. Kritik ganda juga merupakan sebuah pendekatan beragam arah (a multi-headed approach) yang didasarkan atas kritik simultan terhadap beragam komunitas dan wacana di mana setiap orang dapat terlibat di dalamnya. 
Nalar: Jurnal Peradaban dan Pemikiran Islam

Vol. 2, No. 1, Juli 2018

\section{Daftar Pustaka}

Abdullah, M. Amin. 2012. Islamic Studies di Perguruan Tinggi Pendekatan Integratif-Interkonektif. cet. III. Yogyakarta: Pustaka Pelajar.

Auda, Jasser. 2008. Maqosid al-Syariah as philosophy of Islamic Law: Asystem Approach. London: IIIT.

Dzuhayatin, Siti Ruhani dkk. Rekonstruksi Metodologis Wacana Kesetaraan Gender dalam Islam, Yogykakarta: PSW IAIN Sunan Kalijaga dan McGill ICIHEP.

Ehrke, Michael. 2001. 11 September: Attacks on Which Civilization dalam Security Dialogue AsiaEurope, Singapore: Fredrich Ebert Stiftung.

Fanani, Tholhatul Choir dan Ahwan (eds). 2009. Islam dalam Berbagai Bacaan Kontemporer, Yogyakarta: Pustaka Pelajar.

H.T, Wilson. 1989. Sex and Gender, Making Cultural Sense Civilization, Leiden, New York, Kobenhavn Koln E.J.Brill.

Hasan, M. Arfan Mu'ammar, Abdul Wahid dkk. 2013. Studi Islam Perspektif Insider/Outsider, Yogyakarta: IRCiSoD.

Kholis, Setiawan Nur. 2008. Akar-akar Pemikiran Muslim Progresif dalam Kajian al-Qur'an, Yogyakarta: eLSAQ Press.

Majid, Nurcholish. 2008. Islam Doktrin dan Peradaban. Jakarta: Paramadina.

Majid, Nurcholish. "Passing Over, Melintasi Batas Agama". Dalam Pasing Over, Melintasi Batas Agama ed, Jakarta: PT Gramedia Pustaka Utama.

Noor, Farish A. 2006. Islam Progresif: Peluang, Tantangan, das Masa Depannya di Asia Tenggara, terj. Moch. Nur Ichwan dan Imron Rosyadi. Yogyakarta: SAMHA.

Qomar, Mujamil. 2012. Pemikiran Islam Metodologis: Model Pemikiran Alternatif dalam Memajukan Peradaban Islam, Yogyakarta: Teras.

Safi, Omid (ed). 2003. Progressive Muslim: On Justice, Gender, and Pluralism, Oxford: Oneworld. .2006. Voices of Change, Vol. 5 in the 5 volume series: Voices of Islam, Praeger.

Safi, Omid. 2006. The Politics of Knowledge in Premodern Islam, Chappel Hill: UNC Press.

Shihab, Qurasih. 1998. Wawasan Al-Qur'an, Bandung: Mizan.

Taimiyyah, Ibn. 1976. al-Amr bi 'l-Ma'ruf 'l-Nabyi'an 'l-Munkar, ed. Sholah al-Din al-Munajad, Beirut: Dar alKitab al-Jadid.

Wahid, Abdurrahman. 2012. Tuhan Tidak Perlu Dibela, Yogyakarta: LkiS.

Zaqzuq, Mahmud Hamdi. 2004. Al-Islam fi 'Ashr al-Aulamah, terj. Abdullah Hakam Shah (Yogyakarta: Pustaka Pesantren.

Zubaedi. 2013. Islam dan Benturan Peradaban: Dialog Filsafat Barat dengan Islam, Dialog Peradaban, dan Dialog Agama, Yogyakarta: Ar-Ruzz.

Safi, Omid. 2005. Diakses tanggal 19 Desember 2017 dari http://wahidinstitute.org/v1/Programs/Detail/?id=276/hl=id/Gerakan_Muslim_ Progresif_Di_Indonesia. 